\title{
Native parasitoids (Hymenoptera: Braconidae) of fruit flies (Diptera: Tephritidae) in Serra da Bodoquena National Park-MS, Brazil
}

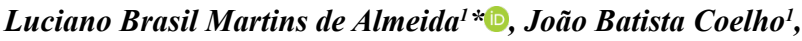 \\ Jorge Anderson Guimarães ${ }^{2} \&$ Manoel Araecio Uchoa ${ }^{1}(\mathbb{D}$ \\ ${ }^{1}$ Universidade Federal da Grande Dourados, Faculdade de Ciências Biológicas e Ambientais, \\ Dourados, MS, Brasil \\ ${ }^{2}$ Embrapa Hortaliças, Brasília, DF, Brasil \\ *Corresponding author: Luciano Brasil Martins de Almeida, e-mail: luciano_b_m@hotmail.com
}

\begin{abstract}
ALMEIDA L.B.M., COELHO J.B., GUIMARÃES J.A., UCHOA M.A. Native parasitoids (Hymenoptera: Braconidae) of fruit flies (Diptera: Tephritidae) in Serra da Bodoquena National Park-MS, Brazil. Biota Neotropica. 19(4): e20190776. http://dx.doi.org/10.1590/1676-0611-BN-2019-0776
\end{abstract}

\begin{abstract}
Fruit flies are among the main groups of phytophagous insects. Their larvae, when feeding on the pulp or seeds of the host fruits, can cause rot and favor the entrance of pathogens. Thus, the objectives of this study was: (1) To know the trophic associations between species of parasitoids and fruit flies in the Parque Nacional da Serra da Bodoquena (PNSB)-MS, Brazil. (2) To inventory the parasitoid species associated with fruit flies in fruit trees in the Parque Nacional da Serra da Bodoquena. Monthly expeditions were carried out (From Jan 2017 to Feb 2018) in order to collect the fruits and obtain the fruit flies (Tephritidae) and their respective parasitoids. The collected fruits were transported to the laboratory of frugivorous insects (LIF) of the Universidade Federal da Grande Dourados (UFGD)-MS. The fruit fly larvae were daily collected and placed in transparent acrylic cups containing sterilized sand, where they remained till the emergence of adults and their parasitoids. Twenty-Three adult Tephritid parasitoids were recovered, represented by two species of Braconidae: Doryctobracon areolatus (18) and Utetes anastrephae (5), both infesting Anastrepha species: Anastrepha fraterculus, A. sororcula and A. striata in Myrtaceae: Psidium guajava and Eugenia myrcianthes. Doryctobracon areolatus and Utetes anastrephae are reported for the first time parasiting Anastrepha species in Eugenia myrcianthes.
\end{abstract}

Keywords: Parasitism, Trophic Interactions, Biological Control, Conservation Unit, Natural Enemies.

\section{Parasitoides Nativos (Hymenoptera: Braconidae) de moscas das frutas (Diptera: Tephritidae) no Parque Nacional da Serra da Bodoquena-MS, Brasil}

\begin{abstract}
Resumo: As moscas-das-frutas estão entre os principais grupos de insetos fitófagos. Suas larvas, ao se alimentarem da polpa ou das sementes dos frutos hospedeiros, podem causar podridão e favorecer a entrada de patógenos. Sendo assim, os objetivos desse estudo foram: (1) Conhecer as associações tróficas entre as espécies de parasitoides e moscas das frutas no Parque Nacional da Serra da Bodoquena (PNSB). (2) Inventariar as espécies de parasitoides no PNSB. Foram realizadas expedições mensais de janeiro de 2017 a fevereiro de 2018 para as coletas de frutos e obtenção de moscas das frutas (Tephritidae) e seus respectivos parasitoides. Os frutos coletados foram transportados ao Laboratório de Insetos Frugívoros (LIF) da Universidade Federal da Grande Dourados-MS. As larvas das moscas das frutas foram diariamente recolhidas e inseridas em copos de acrílico transparentes contendo areia esterilizada onde permaneceram até a emergência dos adultos de tefritídeos e/ou seus parasitoides. Foram recuperados 23 adultos de parasitoides das larvas dos tefritídeos, representados por duas espécies de Braconidae: Doryctobracon areolatus (18) e Utetes anastrephae (5), ambos parasitando espécies de Anastrepha: Anastrepha fraterculus, A. sororcula e A. striata em Myrtaceae: Psidium guajava e Eugenia myrcianthes. Doryctobracon areolatus e Utetes anastrephae são relatados pela primeira vez parasitando espécies de Anastrepha em frutos de Eugenia myrcianthes. Palavras-chave: Parasitismo, Interações Tróficas, Controle Biológico, Unidade de Conservação, Inimigos Naturais.
\end{abstract}




\section{Introduction}

Fruit flies are among the main groups of phytophagous insects. Their larvae, when feeding on the pulp or seeds of the host fruits can cause rot and favor the entry of pathogens, causing the early fall of the fruits and making them unviable for in natura consumption or commercialization (Uchoa 2012).

Natural fruit fly enemies such as viruses, bacteria, fungi, protozoa, nematodes, predators, parasites and parasitoids are important biotic agents of mortality. They are usually present in natural environments and can be handled in labs or biofactories and employed in integrated management programs for species with pest status on vegetables and fruit trees (Stibicky 2004).

The hymenoptera parasitoids, mainly Braconidae, Figitidae and Pteromalidae, are considered the main regulators of fruit fly populations in the Neotropical region (Uchoa 2012). Researches on these trophic interactions have been intensified since the 1970, with advances in scientific investigations on ecology (Cappuccino 1995) and the natural history of fruit fly natural enemies.

There are two main guilds of parasitoids which attack fruit flies: those that parasitize juveniles (first two instars) and the ones that settle in third instar larvae and/or pre-pupae and emerge from the puparium at the end of this phase. The Tetriphid larvae are parasitized still inside the fruits or when they leave their hosts to pupate in the ground. Normally, parasitoids oviposit endophytically in the host, reaching the frugivorous larvae inside the fruit. Upon hatching of the egg, the neonata parasitoid larva will feed and develop internally in the host tephritid larva. Then it will devour the whole pupal musculature, emerging through a hole produced by the imago jaws (Salles 1995; Cirelli \& Dias 2003).

In Brazil, studies on fruit fly parasitoids are still scarce, mainly due to the fact that most of the researches are carried out by using traps which capture the adults of fruit fly species, so it is not possible to obtain the larvae of the tephritids and their emergent parasitoids. The main Braconidae species already inventoried in the country are: Doryctobracon areolatus (Szépligeti), Utetes Anastrephae (Viereck) and Opius bellus Gahan (Canal \& Zucchi 2000, Costa et al. 2009).

The knowledge on Tephritid natural enemies in natural environments, especially in Integral Conservation Units (UCs), is scarce. As these parasitoids are not specific species, they help to regulate fruit fly populations in a natural way and can parasitize the larvae of several species that colonize a large diversity of fruit species, many of commercial value. In addition, these important biotic agents of mortality can be used for the biological control of Tephritids with pest status.

In Brazil, there are currently 73 national parks earmarked for the integral conservation of biodiversity and biotope: North (29), Northeast (8), Midwest (8), Southeast (13), South (15) (MMA, 2019). These units represent excellent sites for studies of biological diversity, since they have their fauna, flora and physical environment preserved. Thus, the objectives of this research were: To know the trophic associations between the parasitoid species and fruit flies in the Parque Nacional da Serra da Bodoquena (PNSB), Brazil; To inventory the parasitoid species associated with fruit flies in fruit trees in the PNSB.

\section{Material and Methods}

\section{Study area}

According to Koppen, the climate in the Parque Nacional da Serra da Bodoquena (PNSB) $\left(20^{\circ} 35-21^{\circ} 30^{\prime} \mathrm{S}\right.$; 56 $\left.36^{\circ} 0^{\prime}-57^{\circ} \mathrm{W}\right)$ is type AW, characteristic of wet Summer and dry Winter (between May and September), with annual rainfall varying between 1.000 and $1.700 \mathrm{~mm}$, reaching the lowest rainfall index in August. The maximum temperature in the dry period is $35^{\circ} \mathrm{C}$ and the average of the coldest month varies between 15 and $20^{\circ} \mathrm{C}$ (PCBAP 1997; Reys et al. 2005).

The predominant vegetation in the PNSB is the Deciduous Seasonal Forest, better known as dry forest, since it is associated with limestone rocks. Next to the water courses occurs the Deciduous Alluvial Seasonal Forest, which corresponds to the ciliary forest. There are also transition areas in the park with characteristics of both Cerrado and Seasonal forest (IBAMA 2000).

The PNSB is compoused by two areas, comprising four municipalities (Jardim, Bonito, Bodoquena and Porto Murtinho) in Mato Grosso do Sul state. To the South (27.793ha) it is located in Porto Murtinho, Bonito and Jardim, and the fragment of the northern part (48.688ha) in Bodoquena and Bonito (PNSB 2013).

The PNSB region is a priority area for the biodiversity conservation in Mato Grosso do Sul, due to its unique characteristics. The park is formed by carbonate rocks which provide the occurrence of clastic features with numerous caves and grottos.

\section{Data collection and analysis}

Monthly expeditions were carried out (from Jan 2017 to Feb 2018) in order to collect the fruits and obtain the fruit flies (Tephritidae) and their respective parasitoids in the PNSB. For this purpose, fruits that were found in both fruit trees and fallen to the ground were sampled, depending on their availability along the pre-established transects, each with $5 \mathrm{~m}$ width $(2,5 \mathrm{~m}$ for each side).

These three trails are used two to four times a year to monitor the flora and fauna in the PNSB. The evaluated trails were: Santa Fé

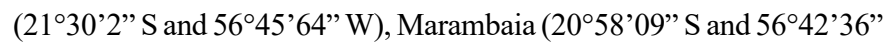
$\mathrm{W})$ and Catamarca (the spring and sink of the Perdido river ( $21^{\circ} 06^{\prime} 90^{\prime \prime}$ $\mathrm{S}$ and $56^{\circ} 42^{\prime} 36^{\prime \prime} \mathrm{W}$ ). (Figures. 1, 2 and 3).

All the sampled plants along the trails were exsicated and their species were identified by Dr. Zefa Valdivina Pereira, Faculdade de Ciências Biológicas e Ambientais (FCBA), Universidade Federal da Grande Dourados (UFGD) and by Dr. Ângela Sartori, from the Departamento de Biologia of Universidade Federal de Mato Grosso do Sul (UFMS), Campo Grande-MS.

The collected fruits were packed in cotton bags and transported to the Laboratório de Insetos Frugivoros (LIF) of the UFGD, DouradosMS, where they were later transferred to wooden pallets allocated in plastic trays containing a fillet of water $( \pm 1 \mathrm{~cm})$ on the bottom, according to Uchoa \& Zucchi (1999) metodology for last instar larvae collection of fruit flies that leave the fruit to pupate. 


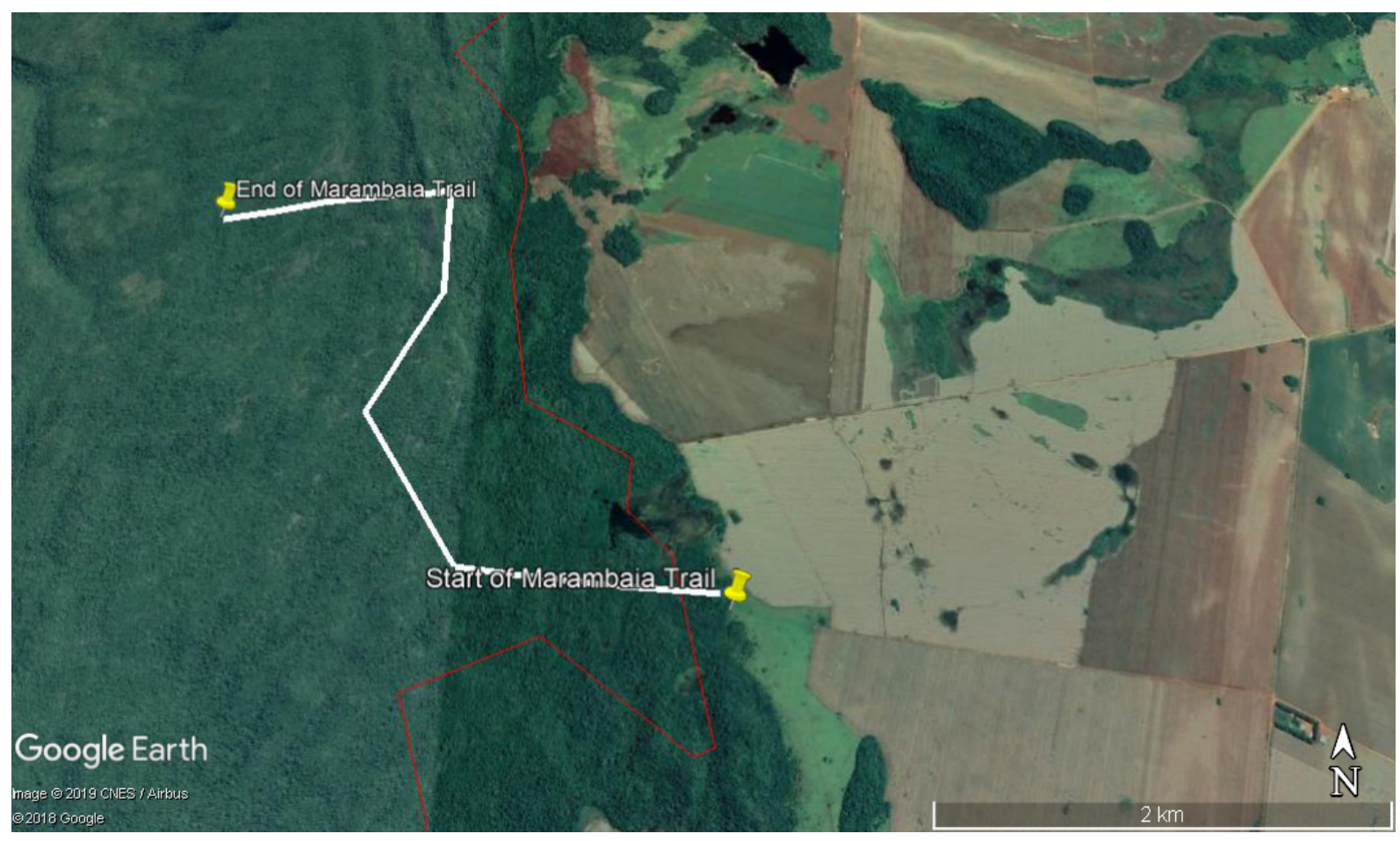

Figure 1. Marambaia Trail in the Parque Nacional da Serra da Bodoquena, Mato Grosso do Sul state, Brazil, used to monitor periodically the flora and fauna (Source: Google Earth, 2019).

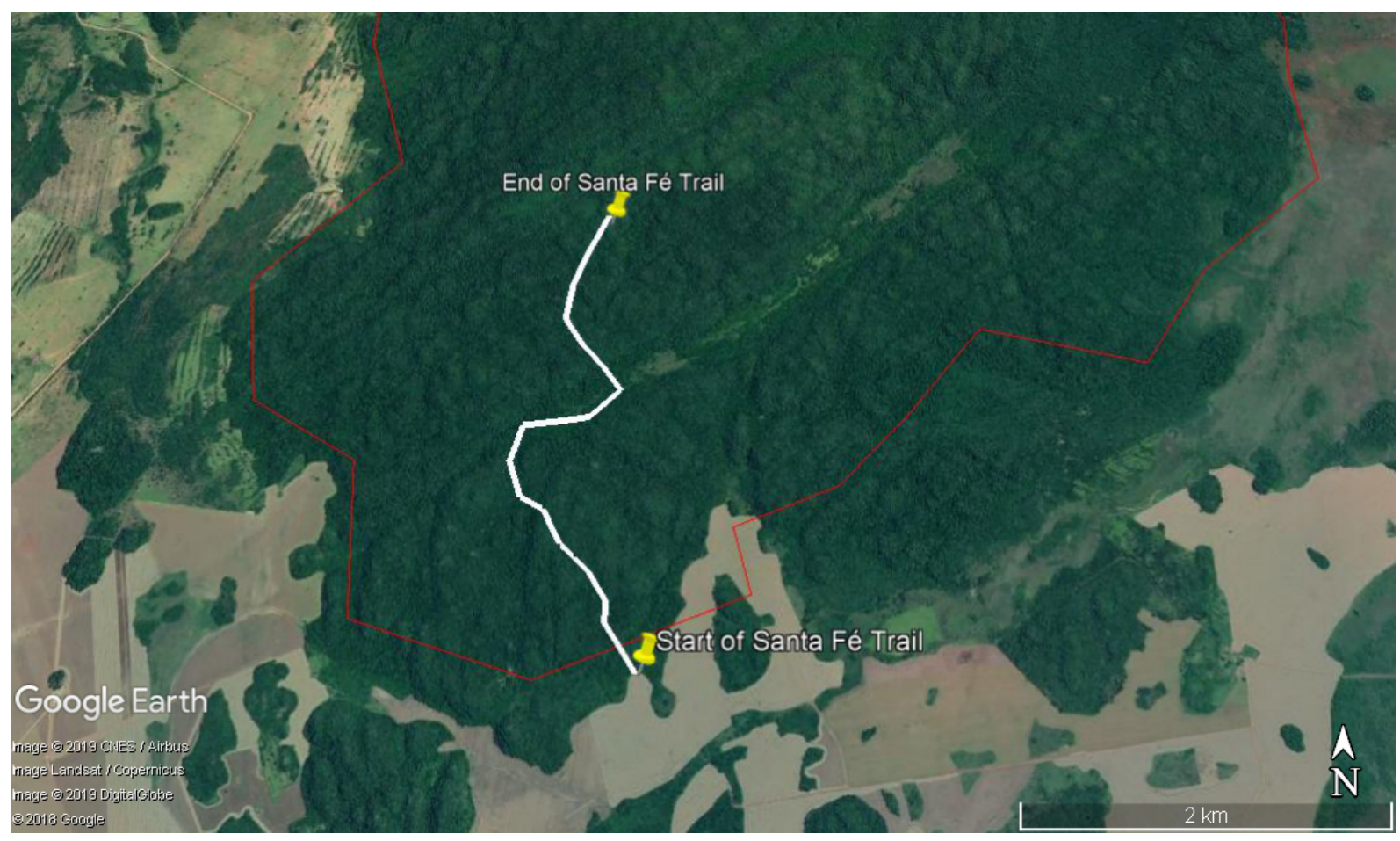

Figure 2. Santa Fé Trail in the Parque Nacional da Serra da Bodoquena, Mato Grosso do Sul state, Brazil, periodically used to monitor the flora and fauna (Source: Google Earth, 2019). 


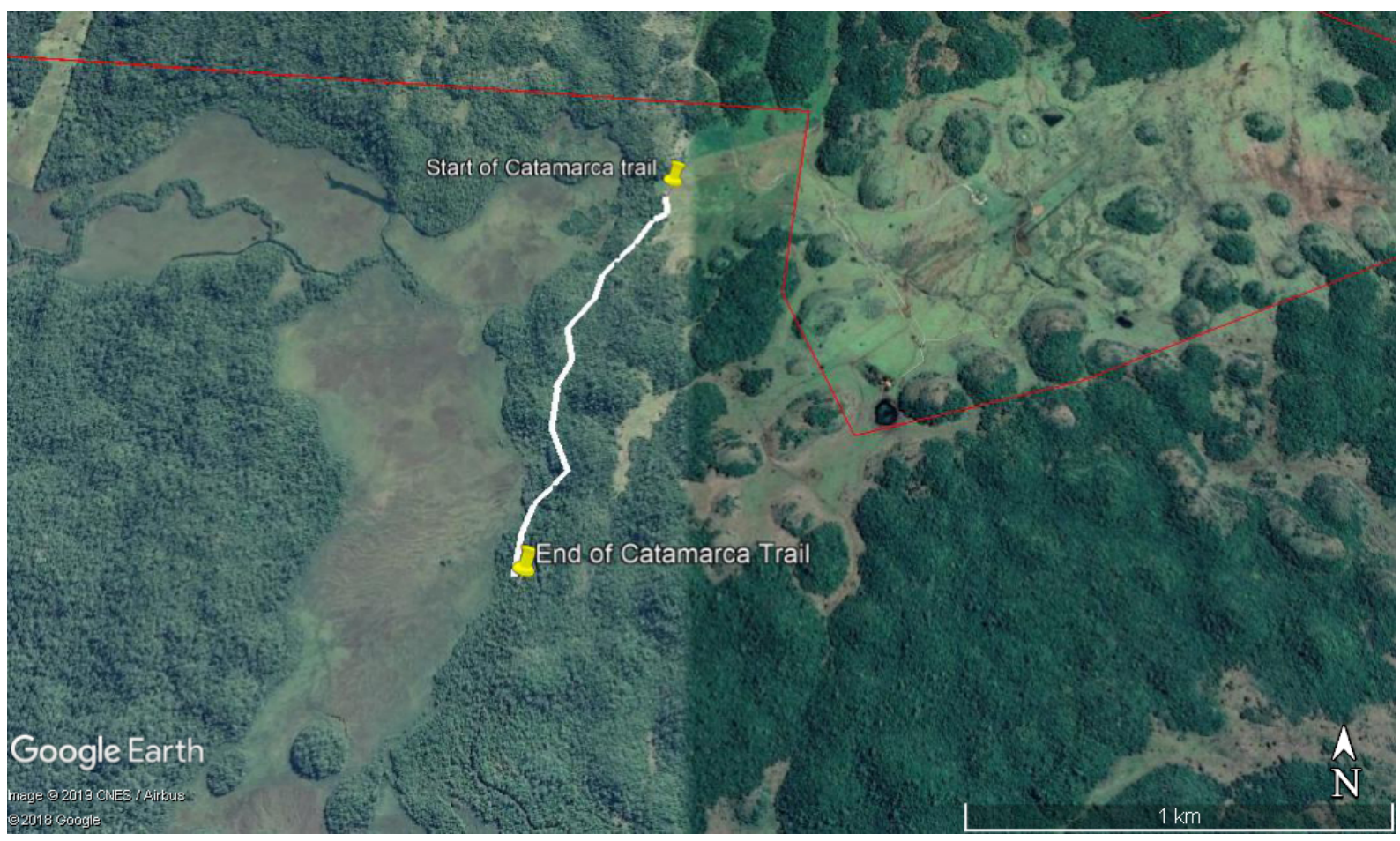

Figure 3. Catamarca Trail in the Parque Nacional da Serra da Bodoquena, Mato Grosso do Sul state, Brazil, used to monitor periodically the flora and fauna (Source: Google Earth, 2019).

The larvae were daily collected from the trays and placed into clear acrylic cups containing sterilized sand, where they remained untill the adult emergence of the fruit flies and/or their parasitoid species.

The identification of frugivorous Tephritid species was performed by the examination of female genitalia by Dr. Manoel Uchoa, in the laboratory using identification keys (Stone 1942, Steyskal 1977, Zucchi 2000).

The identification of the parasitoids emerged from the tephritid puparium was performed by Dr. Jorge Anderson Guimarães, EMBRAPA HORTALIÇAS (CNPH), Brasília-DF, using identification keys (Canal \& Zucchi 2000; Guimarães et al. 2000, 2003, 2011).

The parasitism rates of fruit flies were calculated according to Uchoa et al. (2003), by the equation $\% \mathrm{CP}=$ N.R.P x $100 / \mathrm{N}$. L3, where $\%$ C.P $=$ total percentage of parasitism rate, N.R.P $=$ Number of recovered parasitoids and N.L3 $=$ Number of third instar larvae from recovered the fruit flies.

\section{Results and Discussion}

Twenty-three adult parasitoids were recovered from the tephritid larvae, represented by two Braconidae species: Doryctobracon areolatus (18) and Utetes anastrephae (5), both infesting Anastrepha species: Anastrepha fraterculus (Wiedmann), A. sororcula Zucchi and A striata Schiner in Myrtaceae: Psidium guajava L. and Eugenia myrcianthes (Nied). (Table 1).

The higher abundance of parasitoids occurred in E. myrcianthes, with 10 individuals of $D$. areolatus and three of $U$. anastrephae. In P. guajava, eight adults of $D$. areolatus and two from $U$. anastrephae were obtained. The highest parasitism index was obtained in $E$. myrcianthes, with $6.5 \%$ of parasitism, and in P. guajava the index was $6 \%$, totalizing $12.5 \%$ of parasitized larvae (Table 1 ). The two parasitoid species found in this study (D. areolatus and $U$. anastrephae) are frequently obtained in researches on trophic interactions among fruit flies, host plants and their parasitoids (Uchoa et al. 2003, Marinho et al. 2009).

Doryctobracon areolatus is considered one of the most important native species of fruit fly parasitoids in the Neotropical region. It parasitizes several species of Anastrepha in South and Central America countries (Purcell 1998, Cancino \& Montoya 2004). This species is considered promising for integrated pest management programs, aiming at the biocontrol of fruit flies (Uchoa et al. 2003, Uchoa 2012). Its largest abundance, reported in this study, is probably due to the wide geographic distribution of the species.

The high abundance of $D$. areolatus can be related to its largest ovipositor size $( \pm 3.8 \mathrm{~mm})$ in relation to $U$. anastrephae $( \pm 1.6 \mathrm{~mm})$. Probably this feature enables $D$. areolatus to oviposit in fruit fly larvae in a greater diversity of host fruit species with different sizes and thickness of epicarp and mesocarp (Sivinsky et al. 2009, Marinho et al. 2009).

Utetes anastrephae, as well as D. areolatus, is distributed throughout the neotropical region. This is the only species of Utetes genus recorded parasiting Anastrepha species, with recorded occurence in 20 brazilian states and associated with 16 species of Anastrepha and Ceratitis capitata (Wiedmann) (Zucchi \& Moraes 2008). The lowest abundance of $U$. anastrephae in relation to $D$. aerolatus in the ecosystems has been frequently been reported in other researches (Torres et al. 2010; Falcão et al. 2012), results that are consistant with this study. 
Table 1. Trophic interactions between fruit flies (Diptera: Tephritidae, host plants and parasitoids (Hymenoptera: Braconidae) in the Parque Nacional da Serra da Bodoquena-MS, Brazil (January 2017 and December 2018).

\begin{tabular}{|c|c|c|c|c|c|c|c|c|}
\hline $\begin{array}{l}\text { Botanical } \\
\text { Family }\end{array}$ & Plant species & $\begin{array}{c}\text { Weight } \\
\text { (g) }\end{array}$ & $\begin{array}{c}\mathbf{N}^{\circ} \\
\text { Fruits }\end{array}$ & $\begin{array}{c}\mathbf{N}^{\mathbf{o}} \\
\text { Larvae }\end{array}$ & $\begin{array}{c}\mathbf{N}^{0} \\
\text { Adults }\end{array}$ & Fly species & Parasitoid species & \% Parasitoids \\
\hline \multirow[t]{8}{*}{ Myrtaceae } & $\begin{array}{l}\text { Psidium } \\
\text { guajava }\end{array}$ & 1038 & 65 & 191 & 80 & $\begin{array}{l}\text { Anastrepha sororcula } \\
\text { Zucchi (71) }\end{array}$ & $\begin{array}{l}\text { Doryctobracon } \\
\text { areolatus }(8)\end{array}$ & 6 \\
\hline & & & & & & $\begin{array}{l}\text { Anastrepha striata } \\
\text { Schiner (3) }\end{array}$ & $\begin{array}{l}\text { Utetes } \\
\text { anastrephae (2) }\end{array}$ & \\
\hline & & & & & & $\begin{array}{l}\text { Anastrepha fraterculus } \\
\text { (Wiedman) (1) }\end{array}$ & & \\
\hline & & & & & & Anastrepha spp. (5) & & \\
\hline & $\begin{array}{l}\text { Eugenia } \\
\text { myrcianthes }\end{array}$ & 779 & 133 & 197 & 145 & Anastrepha fraterculus (45) & $\begin{array}{l}\text { Doryctobracon } \\
\text { areolatus (10) }\end{array}$ & 6,5 \\
\hline & & & & & & Anastrepha sororcula (9) & $\begin{array}{l}\text { Utetes } \\
\text { anastrephae (3) }\end{array}$ & \\
\hline & & & & & & Anastrepha spp. (85) & & \\
\hline & & & & & & Neosilba sp. (6) & & \\
\hline Total & & 1,817 & 198 & 388 & 225 & & 23 & 12,5 \\
\hline
\end{tabular}

According to Hickel (2002), the pulp of the fruit can act as a barrier to parasitism, explaining the low abundance of $U$. anastrephae in relation to $D$. aerolatus. This pattern is also recorded in other inventories, such as Uchoa et al. (2003) and Taira et al. (2013). Since Utetes anastrephae ovipositor is shorter than that of $D$. aerolatus, it possibly attacks only larvae in smaller fruits with fine pericarp and a less thick endocarp.

Smaller fruits possibly favor parasitoid species with shorter ovipositor, since they facilitate the encounter of the larvae. On the other hand, parasitoids with long ovipositors can obtain larvae in fruits with pulps of different thicknesses, being able, in a way, to diminish the competition between the two species (D. aerolatus and $U$. anastrephae) by the host fruits (Marinho et al. 2009). In this research, the fruits infested by tephritids were medium in size ( 3 to $5 \mathrm{~cm}$ ), which in a way could have favored the parasitoids with longer ovipositor, such as $D$. aerolatus.

According to Costa et al. (2009), the fruits that are collected from the ground are generally more parasitized than the ones taken directly from the trees. This probably happens due to the longer exposure time of the fruits in the field and also to the behavior of certain parasitoid species which more frequently parasitize larvae in fallen fruits, penetrating through openings previously made by other frugivorous insects or birds. This is another possible explanation for the reduced parasitism verified in this study, since most of the sampled fruits $( \pm 70 \%)$ were collected directly from the fruit trees and not from the ground.

The low richness in parasitoid species is attributed to the low diversity of fruit flies collected in the study area. Doryctobracon areolatus and Utetes anastrephae are reported for the first time in Eugenia myrcianthes fruits. Researches on fruit fly parasitoids are still scarce in UCs, thus, this study contributes to broaden the knowledge about fruit fly natural enemies in conserved areas.

\section{Acknowledgements}

We thank the Instituto Chico Mendes de Conservação da Biodiversidade (ICMBIO) for authorization for this research in the Parque Nacional da Serra da Bodoquena (PNSB) and for the logistic support and facilities to the researcher team; Professor Dr. Zefa Valdivina Pereira, Faculdade de Ciências Biológicas e Ambientais (FCBA), Universidade Federal da Grande Dourados (UFGD, Dourados-MS), and Professor Dr. Ângela Sartori, Departamento de Biologia, Universidade Federal de Mato Grosso do Sul (UFMS-Campo Grande-MS), for identifying the species of plants sampled; Coordenação de Aperfeiçoamento de Pessoal de Nível Superior (CAPES) for the grant awarded to the first author for his master's degree; Fundação de Apoio ao Desenvolvimento do Ensino, Ciência e Tecnologia do Estado de Mato Grosso do Sul (FUNDECT), Coordenação de Aperfeiçoamento de Pessoal de Nível Superior (CAPES): FUNDECT-CAPES-PAPOSMS 44/2014, FUNDECT-CAPES 12/2015-BIOTA-MS-Ciência e Biodiversidade) for financial support.

\section{Author's Contributions}

Luciano Brasil Martins de Almeida: Data collection and analysis; Preparation of the manuscript.

João Batista Coelho: Assistance in data collection.

Jorge Anderson Guimarães: Identification of parasitoid species.

Manoel Araecio Uchoa: Preparation of the manuscript and fruit fly identification.

\section{Conflict of interest}

The authors declare that they have no conflict of interest related to the publication of this manuscript. 


\section{References}

CANAL, N.A \& ZUCCHI, R.A. 2000. Parasitóides - Braconidae. p.119-126. In: MALAVASI, A., ZUCCHI, R.A. (Eds.). Moscas-das-frutas de importância econômica no Brasil. Conhecimento básico e aplicado. Holos, Ribeirão Preto, São Paulo. 327.

CANCINO, J \& MONTOYA, P. 2004a Controle biológico por aumento en moscas de la fruta. Folia Entomol. Mex. 43: 257-270.

CAPPUCCINO, N. 1995. Novel approaches to the study of population dynamics. In: CAPPUCCINO, N., PRICE PW. (Ed.). Population dynamics: new approaches and synthesis. San Diego: Academic press. p.3-16.

CIRELLI, K.R.N \& PENTEADO-DIAS, A.M. 2003. Fenologia dos Braconidae (Hymenoptera, Ichneumonoidea) da Área de Proteção Ambiental (APA) de Descalvado, SP. Rev. Bras. Ent. 47: 99-105.

COSTA, S.G.M., QUERINO R.B., RONCHI-TELES B., PENTEADO-DIAS, M.A.M \& ZUCCHI, R.A. 2009. Parasitoid diversity (Hymenoptera: Braconidae and Figitidae) on frugivorous larvae (Diptera: Tephritidae and Lonchaeidae) at Adolpho Duke Forest Reserve, Central Amazon Region, Manaus, Brazil. Brazilian Journal of Biology 69: 363-370.

FALCÃO de SÁ, R., CASTELLANI, M.A., NASCIMENTO, A.S., RIBEIRO, A.E.L \& MOREIRA, A.A.A. 2012. Parasitismo natural em moscas-dasfrutas (Diptera: Tephritidae) no semiárido do sudoeste da Bahia, Brasil. Rev. Bras. Frutic. 34: 1266-1269.

GUIMARÃES, J.A., DÍAZ, N. B \& ZUCCHI, R.A. 2000. Parasitóides: Eucoilinae p.127-134. In: MALAVASI A.; ZUCCHI, R.A. (Org.). Moscas das frutas de importância Econômica no Brasil: conhecimento básico e aplicado. Ribeirão Preto: Holos Editora 325 p.

GUIMARÃES, J.A., GALLARDO, F.E., DÍAZ, N.B \& ZUCCHI, R.A. 2003. Eucoilinae species (Hymenoptera: Cynipoidea: Figitidae) parasitoids of fruit-infesting dipterous in Brazil: Identity, geographical distribution and host associations. Zootaxa. 278: 1-23.

GUIMARÃES, J.A \& ZUCCHI, R.A. 2011. Chave de identificação de Figitidae (Eucoilinae) parasitóides de larvas frugívoras na região Amazônica. p.103110. In: SILVA, R.A., LEMOS, W.P \& ZUCCHI, R. A. (Ed.). Moscas-dasfrutas na Amazônia brasileira: diversidade, hospedeiros e inimigos naturais. Macapá: Embrapa Amapá 302p.

HICKEL, E.R. 2002. Espessura da polpa como condicionante do parasitismo de moscas-das-frutas (Diptera: Tephritidae) por Hymenoptera: Braconidae. Cienc. Rural. 32: 1005-1009.

IBAMA (2000). Decreto de criação de unidade de conservação $\mathrm{s} / \mathrm{n}$ de 22 de setembro de 2000. (Acessed on March 11, 2019)

MARINHO, C.F., SOUZA-FILHO, M.F., RAGA, A \& ZUCCHI, R.A. 2009. Parasitoides (Hymenoptera: Braconidae) de Moscas das-Frutas (Diptera: Tephritidae) no Estado de São Paulo: Plantas Associadas e Parasitismo. Neotrop. Entomol. 38: 321-326.

MMA. 2019. Ministério do Meio Ambiente. (Acessed on January 17, 2019).

PCBAP. 1997. Análise integrada e prognóstico da Bacia do Alto Paraguai. Ministério do Meio Ambiente dos Recursos Hídricos e da Amazônia Legal, Brasília-DF. 369p.

PNSB: Plano de Manejo do Parque Nacional da Serra da Bodoquena. 2013. ICMBIO-MMA. Brasília-DF. 50p.
PURCELL, M.F. 1998. Contribution of biological control to integrated pest management of Tephritidae fruit flies in the tropics and subtropics. Int. J. Pest Manag. 3: 63-83.

REYS, P., GAletti, M., MORELlato, L.P.C \& SABINO, J. 2005. Fenologia reprodutiva e disponibilidade de frutos de espécies arbóreas em mata ciliar no rio Formoso, Mato Grosso do Sul. Biota Neotropica 5: 1-10. http://www.biotaneotropica.org.br/v5n2/pt/abstract?short tcommunication+bn01205022005.

SALLES, L.A.B. 1995. Bioecologia e controle da mosca-das-frutas sulamericana. Pelotas-RS: Embrapa CPACT. 57p.

SIVINSKY, J., VULINEC, K., ALUJA, M. 2009. Ovipositor lenght in a guild of parasitoids (Hymenoptera: Braconidae) attacking Anastrepha spp. fruit flies (Diptera: Tephritidae) in Southern Mexico. Ann Entomol Soc Am 94: 886-895.

STEYSKAL, G.C. 1977. Pictorial key to species of the genus Anastrepha (Diptera: Tephritidae). Washington, D.C., Entomological Society of Washington 35p.

STIBICKY, J.N.L. 2004. Natural enemies of the Fruit Flies (Tephritidae). United States Departament of Agriculture (USDA), Animal and Plant Health Inspectial Service (APHIS), Plant Protection Quarentine (PPQ), Riverdale, MD, 86p.

STONE, A. 1942. The fruit flies of the genus Anastrepha. United States Department of Agriculture, Miscellaneous Publication. 439, 112p.

TAIRA, T.L., ABOT, A.R., NICÁCIO, J., UCHOA, M.A., RODRIGUES, S.R \& GUIMARÃES, J.A. 2013. Fruit flies (Diptera, Tephritidae) and their parasitoids on cultivated and wild hosts in the Cerrado-Pantanal ecotone in Mato Grosso do Sul, Brazil. Rev. Bras. Ent. 57: 300-308.

TORRES, C.A.S., CASTELLANI, M.A., PÉREZ-MALUF, R., CARLSON, J., SILVA, G., NASCIMENTO, A.S., JOSÉ, A.R.S., MOREIRA, A.A \& FALCÃO, R. 2010. Infestação de cafeeiros por moscas-das-frutas (Diptera: Tephritidae): espécies associadas e parasitismo natural na região Sudoeste da Bahia, Brasil. Pesq. Apl. Agrotec. 3: 131-142.

UCHOA, M.A \& ZUCCHI, R.A. 1999. Metodología de colecta de Tephritidae y Lonchaeidae frugívoros (Diptera: Tephritoidea) y sus parasitóides (Hymenoptera). An. Soc. Entomol. Bras. 28: 601-610.

UCHOA, M.A., OLIVEIRA, I., MOLINA, R.M.S \& ZUCCHI, R.A. 2003. Populational fluctuation of frugivorous flies (Diptera: Tephritoidea) in two orange groves in the State of Mato Grosso do Sul, Brazil. Neotrop. Entomol. 32: 19-25.

UCHOA, M.A. 2012. Fruit Flies (Diptera: Tephritoidea): Biology, Host Plants, Natural Enemies, and the Implications to Their Natural Control, pp. $217-$ 300. In: Larramendy ML, Soloneski S. (ed.). Integrated Pest Management and Pest Control Current and Future Tactics. InTech. Rijeka, Croatia, 668p.

ZUCCHI, R.A. 2000. Taxonomia. In: MALAVASI, A., ZUCCHI, R.A. Moscasdas-frutas de importância econômica no Brasil: Conhecimento básico e aplicado. Ribeirão Preto: Holos 13-24.

ZUCCHI, R.A \& MORAES, R.C.B. 2008. Fruit flies in Brazil Anastrepha species their host plants and parasitoids. Available in: www.lea.esalq.usp. br/anastrepha/, updated on September 17, 2018. (Acessed on: December 20, 2018) 